\section{BA Institute of \\ YK Business Administration \\ TK \\ Karachi \\ Leadership and Ideas for Tomorrow}

Business Review

Volume 13 Issue 2 July-December 2018

$1-3-2019$

\title{
The entrepreneurial cognition process in a hostile business environment: A study of successful Pakistani entrepreneurs
}

\author{
Mohammad Asad llyas \\ Institute of Business Administration, Karachi, Pakistan \\ Severine Le Loarne \\ Department of Management \& Technology, Grenoble Ecole De Management, France \\ Wajid Hussain Rizvi \\ Institute of Business Administration, Karachi, Pakistan
}

Follow this and additional works at: https://ir.iba.edu.pk/businessreview

\section{(c) (9)}

This work is licensed under a Creative Commons Attribution 4.0 International License.

\section{Recommended Citation}

Ilyas, M. A., Loarne, S. L., \& Rizvi, W. H. (2019). The entrepreneurial cognition process in a hostile business environment: A study of successful Pakistani entrepreneurs. Business Review, 13(2), 94-116. Retrieved from https://doi.org/10.54784/1990-6587.1032 


\title{
The entrepreneurial cognition process in a hostile business environment: A study of successful Pakistani entrepreneurs
}

\author{
Mohammad Asad Ilyas . \\ Severine Le Loarne • Wajid Hussain Rizvi
}

\begin{abstract}
This study observes and documents the entrepreneurial cognition process in the hostile business environment of Pakistan. It focuses on the business strategies deployed by successful entrepreneurs whose companies have exhibited tremendous growth in the past and hold considerable potential in the future. It provides an insight of the hostile environment these high performers experience, the way the entrepreneurs conceptualize the situation and identifies their response strategies as a product of the entrepreneurs' cognitive processing.
\end{abstract}

Keywords Entrepreneurship · Hostile business environment · Business strategy $\cdot$ Cognition process.

\section{Introduction}

In the past, many researchers have examined the relationship between business performance and hostile business environments. However, these researchers studied them at macro level, overlooking the importance of entrepreneurial cognition process and resulting business strategies; and failing to define a hostile business environment by considering other emerging variables e.g. terrorism and violence. The objective of this research study is to observe the entrepreneurial cognition process within the hostile business environment of Pakistan at firmlevel (micro level), the resulting formulation and implementation of business strategies and eventual impact on firm performance.

Businesses exist to fulfill the demands of the society. Hall (1980) stated that survival and prosperity are possible even when the business environment turns

Mohammad Asad Ilyas

Institute of Business Administration, University Road, Karachi-Pakistan

E-mail: ailyas@iba.edu.pk

Severine Le Loarne

Department Management \& Technology, Grenoble Ecole De Management, France

Wajid Hussain Rizvi

Institute of Business Administration, University Road, Karachi-Pakistan 
hostile and industry trends change from favorable to unfavorable. Thus, a hostile environment may hamper some businesses but it also offers great investment opportunities and provides a landscape for reinvestment for those in the industry who are insightful enough to capitalize on it.

Since the end of cold of war, Pakistani citizens and investors have lived in a hostile environment. Pakistan had not yet fully recovered in the twenty years since the end of the cold war when another war i.e. the war on terror came knocking at its doorstep. During the course of research, it was noted that citizens and businesses in Pakistan considered additional factors and variables in their perceptions of hostility in the external environment. These factors were unique to this environment due to persistent political instability, corruption, street crimes, violence and terrorism. Despite the growing threats and hostility, Pakistani businesses demonstrated continuous resilience which is reflected by the bullish trend in Pakistani stock markets.

The business environment directly influences the business through action and cognition. The cognitive process results in the entrepreneur's effectual framing of tasks that leads to the inclusion of a strategy and a set of alternative responses to a decision task (i.e., framing a response to changing business environments) (Mitchell et al 2007). Previous researchers demonstrated that there is a cognition process involved in opportunistic adaptation and subsequent growth that the entrepreneur's cognitive attributes strongly influences (Cooper et al 1991). Forbes (1999) identified ways that recognition and categorization of threats and opportunities can lead to adaptive responses in business. These researchers identified the significance of entrepreneurial cognition in shaping business strategies, but failed to determine how the external environment influences this cognitive process (Mitchell et al 2007).

There are many theories about resilience and functioning in business, but they are not empirically verified and fail to be of practical benefit (Miller 2011). This research aims to observe viable cognition processes and strategic approaches for businesses to successfully survive in hostile environments. This may guide future successful coping strategies and mechanisms for businesses in hostile environments. The researchers did not intend to identify any new coping mechanism or strategy for survival in a hostile environment but rather to observe the entrepreneurial cognition process in the existing hostile environment, the resulting business strategies and their impact on firm performance. The researchers have documented the ways business managers adapt in the Pakistani context and identified (a) how terrorism and violence exacerbate the hostility of the business environment; and (b) how business managers respond through their business strategy to mitigate the effects of the hostile business environment.

In an environment which is in perpetual state of flux, terrorism and mafias influence the economy. There are direct costs that a society pays through high taxes to support military operations, the police and court systems, and infrastructure to counter terrorism and violence. Other than that, there are also indirect costs of acts of terror and crimes in the form of loss of life, reduced business activity, and loss of infrastructure (Greenbaum et al 2007).

Despite studies at the macro level, current literature is very thin regarding 
the impact of terrorism on businesses in the local economy at a micro level (Greenbaum et al 2007). The focus of this study are entrepreneurs operating in Pakistan. The results may not be generalizable to entrepreneurs in similar situations in other countries. Different environments may react differently to environmental hostility, depending on the interplay of macro and micro variables in the economy at large. Hence, the current study is geographically limited. Another limitation of the current research is statistical discrepancy. There is a dearth of data and literature about criminal statistics and criminal activities in the business sector, which limits the analysis.

\section{Literature review}

\subsection{Business environment}

Business environment is a complex and dynamic system which has far reaching effects on firms' performance. Understanding the dynamics of business environment is of utmost importance as firms do not operate in isolation. For survival and growth, firms must assess their internal strengths and weaknesses, and the opportunities and threats presented by the external environment (Eruemegbe 2015).

As per the literature the business environment consists of all external factors that surround a firm and to which a firm is exposed directly or indirectly (Eruemegbe 2015). Business environment merits careful study and analysis as it helps firms in remaining competitive, formulating effective strategies and counter strategies, and influencing and harmonizing the environment with organizational goals (Eruemegbe 2015).

\subsubsection{Hostile business environment}

An environment is considered to be hostile when businesses and firms face an unfriendly atmosphere that is full of intense competition, regulatory restrictions, shortage of resources, uncertainty and unpredictability (Covin and Slevin 1989). Khandwalla $(1976,1977)$ identified a hostile environment as a stressful environment with very few business opportunities. Kotey et al (2014) describes hostile environment as adverse climatic conditions, unfavorable terms of trade and currency movements. Hostile business environments are multifaceted with intense competition and upward/downward swings.

The key characteristics of a hostile environment as described in the literature are dynamism, heterogeneity, uncertainty, intense competition, regulatory landscape, threats to organizational goals, and political and economic instability (Lindelöf and Löfsten 2006; Miller and Friesen 1983; Wernerfelt and Karnani 1987; Zhu and Matsuno 2016). Changes in business environment increase environmental uncertainty. A company cannot change the external environment in a competitive marketplace but can take the factors of the environment into consideration and can develop competencies to adapt and exploit the opportunities faster than the competitors (Ivančić et al 2017). 


\subsection{Entrepreneurial cognition process}

The entrepreneurial cognition process consists of entrepreneurial traits such as knowledge (education), self-efficacy, and the ability of the entrepreneur to maintain focus within the hostile business environment. The researchers deduced from studies by Ács and Audretsch (2006), Goulas and Zervoyianni (2013), and Abadie and Gardeazabal (2008) that entrepreneurial focus decreases in a high uncertainty environment. Therefore, the researchers added this variable in the entrepreneurial cognition process. Self-efficacy was already an established entrepreneurial trait (Bandura 1999). Situational state (motive consistent/motive inconsistent), motivational state (aversive/appetitive), probability (certain/uncertain), and control potential (low/high) lead to negative emotions (fear) or positive emotions (hope) (Roseman 1996). Mitchell et al (2002) have defined knowledge as the basis of entrepreneurial cognition process.

Mitchell et al (2002) shifted researchers' focus onto entrepreneurial cognitive abilities. Cognitive abilities relate to knowledge bases, heuristics, cognitive adaptability, and education. Mitchell et al (2002) defined entrepreneurial cognitions as follows: "entrepreneurial cognitions are the knowledge structures that people use to make assessments, judgments or decisions involving opportunity evaluation, venture creation and growth". Entrepreneurial cognition, as it relates to opportunity recognition, is the least studied area in entrepreneurship literature (Mitchell et al 2007). There is cognition involved in opportunistic adaptation; subsequent growth is strongly influenced by the entrepreneur's cognitive attributes (Cooper et al 1991), which depend on past experiences and perceptions (Klepper 2002).

The social cognitive theory of Wood and Bandura (1989) states that at the individual level certain factors enable a person to change their course of life by selecting, influencing and constructing their own environment. Personality traits and behavioral cognition are important entrepreneurial characteristics (Hayton et al 2002). Recent studies identified the influence of contextual factors on entrepreneurial traits. Mitchell et al (2000) identified that risk-taking behavior, a personality trait, also influences other contextual factors.

Early studies linking entrepreneurial characteristics to growth outcomes produced weak results. For example, Johnson (1990) conducted a meta-analysis of achievement as a significant trait predictor of new venture performance; however, less than $7 \%$ of the variance in new venture performance relates to this factor. Traits such as risk-taking propensity (Brockhaus Sr 1980) or locus of control (Sexton and Bowman 1985) had negligible effects on new venture growth. This prompted scholars to study entrepreneurs' characteristics (Gartner 1989). However, Baum et al (2001) found that entrepreneur characteristics have an indirect rather than a direct effect on the growth of firms.

\subsection{Business strategies}

A successful business strategy leads to a successful business; it is the map that guides business operations and development towards sustainable growth. According to Bonini and Görner (2011), a successful business strategy has three 
primary values: growth, risk management, and ROI. According to Vagnoni and Khoddami (2016), strategy helps in setting direction, focusing effort, defining organization and providing consistency. Businesses respond to the challenges presented by hostile business environment through various strategies (Lindelöf and Löfsten 2006).

A successful business strategy for a business is a means for survival in a dynamic business environment and crucial to achieve its goals and objectives by creating a primary advantage, excellence and differentiation (Agyapong et al 2016; Arieftiara et al 2017; Kyrgidou and Hughes 2010). Business strategy is a significant determinant that measures the strength of a firm's internal control over financial reporting (Bentley-Goode et al 2017). Davis et al (1991) describe entrepreneurship as a proactive response to the increasing dynamic, threatening and hostile business environment.

\subsection{Gaps in literature}

Literature seems to be limited in defining hostile business environment. Due to this limitation, business strategies seem to revolve around previous ambiguous concepts. A number of studies have been conducted to assess the impact of hostile business environment on an economy but literature fails to provide enough evidence to assess its impact on firm's performance (Adomako et al 2018).

The existing definitions are also overlapping and describing same phenomenon with different terms. For example, dynamism has been identified as an important characteristic of hostile business environment and on the other hand dynamism has been characterized as a broader term and a phenomenon that contains hostility as well as uncertainty (Campos et al 2015; Torkkeli et al 2012). Some scholars have identified uncertainty as a characteristic of a dynamic environment (Campos et al 2015) while others have characterized uncertainty as an inherent characteristic of a hostile environment (Covin and Slevin 1989). Miller and Friesen (1983) have used dynamism and uncertainty as synonyms. The literature also lacks in establishing the relationship between hostile business environment (dynamism) and firms' performance in case of less developed economies (Adomako et al 2018).

Terrorism is one of the biggest threats to human life, property and economic condition of the world. Al Qaeda, Taliban of Pakistan, ISIS, Islamic State of Iraq and Syria and other terrorist organizations present a direct threat to the world economy as well the economies, businesses and finances of the countries of their operations (Orbaneja et al 2018). Past researchers identified variables such as competition, high risk, and regulatory landscape that form a hostile environment. However, they failed to acknowledge terrorism and violence variables that are especially prominent in the business environments of underdeveloped and developing economies. Past macro level research studies are quantitative and take a holistic view of the phenomenon. A lack of focus on details prompted the need of research at the micro level to understand how terrorism affects businesses. This is one of the fundamental gaps in the research related to businesses and environmental hostility. 
Another important factor that seems to be missing in the previous studies is the role of the entrepreneur in scanning the business environment and business strategy making. Studies like Kaplan (2008) and Hall (1980) are focusing on the relationship between business environment and strategy adaption to gauge the firm's success. Studies by Garbuio et al (2018); Omar et al (2016) focus on business strategies and the entrepreneur but ignore the business environment. There is also a diversified opinion to define the basis of a start of an entrepreneurial activity. Some authors have regarded the risk taking behavior to be the key condition and on the other hand some have defined innovation as central point of innovation (Rususup et al 2012).

Entrepreneurs and SMEs are shaken up to the roots by a hostile business environment. However, literature lacks examples and strategies that are best suited for entrepreneurs and SMEs. The main thrust of literature is towards devising strategies for large firms. Research is generally around firm level, i.e. macro level, which also lacks in-depth analysis, careful consideration and attention to details. In order to academically or empirically prove the premise, quantitative approach is being applied by just getting questionnaires filled by the managers that are too standard and lack genuineness (Miller 2011). This has also been acknowledged as a gap in literature and one of the objectives of this study is to highlight and document micro-level behavior and responses in a hostile business environment.

The business strategy theories have not been observed at micro level in a hostile business environment as highlighted in this literature review. The related literature does not clearly connect business strategies to specific environments (Covin and Slevin 1989). Researchers have explored the link between the environment and strategy formulation, implementation, and evaluation. Many theorists agree there is a relationship between strategy formulation and implementation in the context of the larger macro environment, however, there is negligible research that proves this claim (Miller and Friesen 1983).

Forbes (1999), after an in-depth review of literature, noted that existing studies of both pre-founding and founding cognition emphasized the content instead of the process of cognition. Entrepreneurship researchers only recently began investigating how entrepreneurs think. The terminology for this cognitive process, entrepreneurial cognition, evolved: "entrepreneurial cognition is about understanding how entrepreneurs use simplifying mental models to piece together previously unconnected information that helps them to identify and invent new products or services and to assemble the necessary resources to start and grow business" (Mitchell et al 2002). The terms cognition process, cognition, and entrepreneurial cognition appear interchangeably throughout the literature.

Previous entrepreneurship researchers analyzed new venture strategic behavior and developed firm-level constructs such as entrepreneurial orientation or entrepreneurial strategic-posture (Covin and Slevin 1989; Lumpkin and Dess 1996). These researchers explored constructs that capture an entrepreneur's propensity to act on market opportunities, but these concepts do not fully capture the extent to which opportunistic adaptation is dependent on the entrepreneur's interpretation and information processing capabilities (Cooper et al 
1991; West III and Meyer 1998).

There is limited understanding at specific firm level of the conditions under which entrepreneur improvisational behavior can effectively drive success (Adomako et al 2018). Main stream business strategies mostly revolve around big entities but there is little literature for entrepreneurs on how to manage success as well as setbacks. Incorporating any strategy needs the assessment of its cost. The application of recommended and suggested strategies need considerable amount of time, investment and energy. Therefore, the thrust of this research is towards devising a conceptual strategic framework and model that captures the influence of external environment factors on the thought process and decision making of an entrepreneur given the constraints he or she faces.

This literature review highlighted the gaps in the literature and the importance of context, updated elements in the hostile business environment, entrepreneurial cognition processes, and subsequent entrepreneurial action(s). This study is an effort to observe and document the responses of individuals and entrepreneurs operating under a hostile business environment; and by using an interdisciplinary approach, suggest a holistic model that incorporates and documents the micro level insights that have been missing in literature.

\section{Methodology}

In the absence of any substantive and holistic research related to hostile environment and business responses and strategies in that hostile environment, a need for observation of phenomenon of the hostile business environment was apparent. Given the dearth of information and relevant data in prior literature regarding the impact of violent crimes and terrorism on firm-level (micro level) factors, the researchers conducted an observation of the phenomenon. Based on this concept, the researchers divided the research into three areas:

- definitions of a hostile environment according to business heads;

- their cognition processes in light of their conceptualizations of the hostile environment; and

- business strategies (response) of entrepreneurs after they conceptualized the hostile environment.

The researchers proposed that the interplay of these three areas would impact the firm's outcome. It is important to gain insight into the hostile environment that high performers experience, the way entrepreneurs conceptualize the hostile environment in which their companies operate before their cognitive process, and the business strategies that they employ within this hostile environment. Before collecting data from organizations, the researchers defined the research questions to highlight the topics to be measured and avoid losing focus or becoming overwhelmed by the data (Eisenhardt 1989b). After an exhaustive literature review that informed the creation of a new theoretical model, the research questions became apparent. 


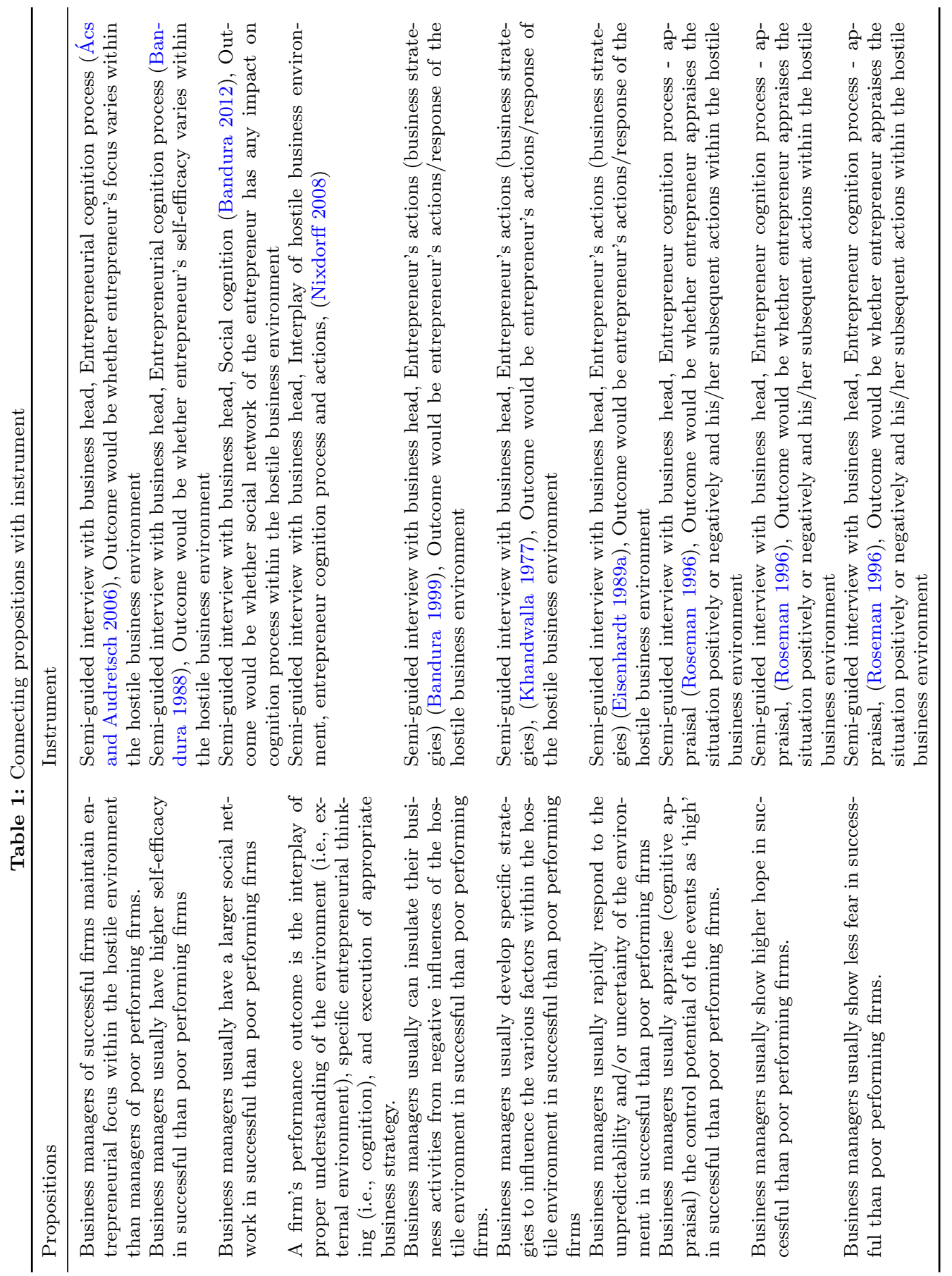


- How do business managers respond/adapt their business strategy to a hostile (terrorism and violence) environment?

- How do terrorism and violence influence the hostility of the business environment?

- How do business managers respond to hostile business environments and sustain their business activities?

The researchers translated the research question into different areas of the semiguided questionnaire. Propositions highlighted different variables for investigation in the field and provided direction to the research (see table 1).

The companies in this group are local entrepreneurial ventures that deal with the manufacturing and marketing of different products (e.g., clothes, food product, pharmaceuticals, PVC piping systems). The selection of companies and data sources used theoretical sampling. The researcher identified extreme sample companies / businesses to illuminate issues businesses face, their response strategies, and the eventual outcome of these strategies. For theory building, the size of the sample is not important, but the identification of the phenomenon is (Eisenhardt 1989b). At a later stage (observation of a phenomenon), future researchers may test them empirically on a larger sample size. The criteria to classify these companies as high performers was a revenue growth rate, in excess of $20 \%$ on an annual basis. Table 2 lists the industry and growth rate of the selected entrepreneurial companies.

Through the study of literature, in-depth primary interviews of entrepreneurs that were validated through secondary interviews with second in commands / core team of these five firms, as well as ten similar firms operating in same industry, five major traits and elements were identified to be the key ingredients of entrepreneurial cognition process that make or break a successful strategy. These major traits are Entrepreneurial focus, Self efficacy, Appraisal of events with high control potential, Fear and Hope. Along with these major traits, following variables were also found to be part of the interplay: Vision, Ethics, Knowledge and Education. Based on these parameters, the decision making process and the business/response strategies during the hostile business environment of these high performing firms were observed and documented.

\section{Results}

4.1 Characteristics of a hostile business environment

\subsubsection{Terrorism and violent crimes}

All the entrepreneurs had personally experienced violent crimes. Entrepreneur A (Company A) stated that he had been a target of road crimes while in a car or waiting at a signal with no guarantees that at the next stop he would not get robbed again. Company B had fortified their factory and head office with security guards, as owners, business heads and employees were frequently threatened. The Managing Director of the pharmaceutical company where Entrepreneur C (Company C) used to work had been kidnapped and Entrepreneur 
$\mathrm{C}$ had been involved in the negotiation and release of the Managing Director. Entrepreneur D's (Company D) brother-in-law had been kidnapped, and many of his friends' children had been kidnapped. Entrepreneur E of Company E had been shot at during a kidnapping attempt that he had resisted on his way to work. All the entrepreneurs in this category had direct experience with violent crimes like kidnapping, robbery, and extortion. For them such violent crimes were a part of the hostile business environment.

Table 2: Company profiles

\begin{tabular}{lccc}
\hline Company name & Owner & Industry & Annual growth rate \\
\hline Company A & Entrepreneur A & Food Product & 0.21 \\
Company B & Entrepreneur B1 & Textile & 0.6 \\
Company C & Entrepreneur C & Pharmaceutical & 0.27 \\
Company D & Entrepreneur D & Pharmaceutical & 0.2 \\
Company E & Entrepreneur E & Pipe manufacturing & 0.4 \\
\hline
\end{tabular}

\subsubsection{Regulatory inefficiencies}

The entrepreneurs believed that the weak regulatory system of the country was the root of all evil, including terrorism and violent crimes. Regulatory inefficiencies comprised of weak drafting, implementation, and control of laws, regulations and governmental agencies.

Lack of governance and unfair, lawless, and corrupt practices within the country are evident when the entrepreneurs have to interact with the FBR and the taxation departments of the country. Entrepreneur B2 recalled the time when the FBR had slapped his company with section 40b, of the sales tax ordinance. Suspicious of the significant growth the company was showing, the FBR officials came and sat in their premises for two months and monitored retail and manufacturing operations to ensure that they (company B) were not involved in any illicit activities.

Entrepreneur A of Company A, Entrepreneur B2 of Company B, Entrepreneur $\mathrm{C}$ of Company $\mathrm{C}$ and Entrepreneur $\mathrm{E}$ of Company $\mathrm{E}$ asserted that regulators created the hostile business environment. Entrepreneur D of Company D chose not to classify whether it was intentional or unintentional. They all agreed that regulators are direct beneficiaries of the situation and it is not in their interest to improve the regulatory environment. According to Entrepreneur E of Company $\mathrm{E}$, the entire industry thrives on corruption, violent crimes, and terrorism.

\subsection{Impact of the hostile environment on entrepreneurs' business}

Weak institutional regulations within the country (intentional or unintentional) create obstacles and exacerbate other negative factors within the business environment. It effects revenue generation capabilities and creates barriers to achieving profitability effects. Mobile phone snatching and threat to life creates stress that reduces the creativity and problem-solving skills of the employees. As a 
consequence of the fear, foreign clients do not visit the country, reducing orders and exports. It stalls the transfer of technology and the introduction of innovative products and services within the country.

Human resource (HR) development suffers, which forces companies to either develop these resources internally or sacrifice growth due to their unavailability. This affects the company's ongoing operations and its expansion goals. It also results in the deterioration of the overall morals and ethics of the society. This is evidenced by the fact that income tax payers declined from 2.7 million income tax filers in 2007 to less than 1.1 million in 2017.

\subsection{The entrepreneurial cognition process}

To be successful, companies must not only possess the required skills but also a resilient self-belief in their capability to exercise control over events to accomplish desired goals (Bandura 1988). Hope (optimism) and fear (pessimism) emerge in response to events that seem uncertain. Hope (optimism) is a positive emotion and fear (pessimism) is a negative emotion (Roseman 1996). Situational state (motive consistent/motive inconsistent), motivational state (aversive/appetitive), probability (certainty/uncertainty), and control potential (low/high) can lead to negative (fear) or positive (hope) emotions (Roseman 1996).

In a hostile environment, the situational state is usually motive inconsistent and the probability of success and control of the situation is low. Therefore, the only factor in control of the entrepreneur is the motivational state (aversive/appetitive), highlighted as a personality trait related to focus and selfefficacy (Bandura 1988).

The focus of the present study is on observation and documentation of the cognition process of entrepreneurs, and how these may facilitate responses to hostility in the business environment. The researchers also considered other variables that frame entrepreneurs' responses to environmental hostility. It is critical to note that entrepreneurial cognition interacts with the hostile business environment to give way to successful or unsuccessful business strategies implemented during hostile situations with hopes of sustaining the business.

\subsubsection{Entrepreneurial focus}

Entrepreneurial activity is often high in a society that experiences rapid expansion (Ács and Audretsch 2006). Goulas and Zervoyianni (2013), concluded that the effect of increased crime on economic growth is asymmetric: as uncertainty regarding the prospects of the economy increases, increasing levels of crime become more harmful to growth. According to Abadie and Gardeazabal (2008), terrorism adds to uncertainty in the business environment and reduces the return on investment.

This implies that in societies that suffer from unstable, risky environmental factors (e.g., terrorism), entrepreneurial activity is subdued. This leads to contraction of the economy at the macro level. The researchers, propose that 
a business that continues to focus on its economic activity and does not get subdued will eventually be successful in such an environment. High performing entrepreneurs admitted that their businesses operate in hostile environments and are under stress. Yet, they managed to remain focused on their objectives. These entrepreneurs were successful due to an unwavering focus on the growth of their companies through innovation, excellence in quality, workforce development, and attention to their customer needs.

Entrepreneur A of Company A had propelled the company to grow at a steady pace of more than $20 \%$ per year over the last eight years solely due to his focus on industrial customer needs, research and development (R\&D), and product quality. Company B had also expanded from 14 outlets to 41 outlets since 2011, growing more than $60 \%$ per year. Entrepreneur B had divided the company into two separate divisions, one focusing on marketing and retail and the other specializing in manufacturing of products. Company $\mathrm{C}$, is now building a new facility costing USD 250 million for use in the year 2018. This will increase their production capacity and range of products, and will also create overall efficiency in the system by reducing the overall unit price.

Entrepreneur D of Company D focuses on organic growth by maintaining

Table 3: Entrepreneurial focus

\begin{tabular}{cccc}
\hline$\#$ & Company & Proposition variable & Presence \\
\hline 1 & Company A & Entrepreneurial focus & $\mathrm{Y}$ \\
2 & Company B & Entrepreneurial focus & $\mathrm{Y}$ \\
3 & Company C & Entrepreneurial focus & $\mathrm{Y}$ \\
4 & Company D & Entrepreneurial focus & $\mathrm{Y}$ \\
5 & Company E & Entrepreneurial focus & $\mathrm{N}$ \\
\hline
\end{tabular}

the sole manufacturing and distribution agreements with multi-national pharmaceutical companies. He focuses on increasing production capacity by adding generic drugs to the company's portfolio. Entrepreneur E of Company E, on the other hand, mainly focuses on daily operations to meet seasonal demands. His sole focus is to maintain the existing business himself without additional support. He did not develop a workforce to eventually help sustain the operations. Kidnapping attempts made him risk averse and he also dropped the idea of training his children to become business successors.

\subsubsection{Self-efficacy}

When faced with difficulty, people with stronger self-belief exert greater effort to meet the challenge (Bandura and Cervone 1983; Jacobs et al 1984). People with self-doubt settle for a mediocre solution (Bandura and Cervone 1983; Jacobs et al 1984). The quality of self-efficacy directly relates to the theory of entrepreneurship (Krueger Jr and Brazeal 1994). Such traits may also exist in an organization at the managerial or employee level. There is a correlation between high self-efficacy and acceptance of a challenge in the business environment (Bandura and Cervone 1983; Jacobs et al 1984). The researchers, therefore, 
propose that business managers with high self-efficacy accept the high hostility in the environment.

Entrepreneurs and business leaders generally have high levels of self-efficacy. This facilitates their survival and success in turbulent times and hostile situations. Such leaders have an internal locus of control and take complete responsibility for their actions.

Entrepreneur A of Company A, recalled the inhibition and self-doubt of his colleagues and peers during the launch of a new plant. However, being a self-confident entrepreneur with clarity of vision, he had assured people that the operations would be successful. Entrepreneur B2's goal was to prove that company objectives will not suffer due to attacks from the regulators. With his entrepreneurial self-efficacy, he ensured that all sales and production targets were met during that period. Entrepreneur C of Company C proved himself through focus on $\mathrm{R} \& \mathrm{D}$, an efficient value chain, and workforce development.

Entrepreneur D of Company D positioned every problem as solvable except

Table 4: Entrepreneurial self efficacy

\begin{tabular}{cccc}
\hline$\#$ & Company & Proposition variable & Presence \\
\hline 1 & Company A & Self efficacy & Y \\
2 & Company B & Self efficacy & Y \\
3 & Company C & Self efficacy & Y \\
4 & Company D & Self efficacy & Y \\
5 & Company E & Self efficacy & N \\
\hline
\end{tabular}

for death. He talked about not losing hope even if faced with a terminal illness. He stated that at any given time business is not easy. It is not supposed to be easy, but his company had reached a point where no one in the industry could beat them. Entrepreneur E of Company E believed in hard work. Through hard work, he overcame poverty and family disputes. He did not have confidence related to the prospects of his company because he felt that his children are not tough enough to take the company to the next level. His low self-efficacy results in his belief that if he shut down his business and went out to look for a job, no one would offer him a job worth even USD 100 a month. Another reason that Entrepreneur E continues the business is because of the working capital (over USD 50 million) stuck with the wholesalers / retailers that his company supplies to.

\subsection{Appraisal of events with high control potential}

As discussed in the literature review related to cognitive appraisal, if an entrepreneur appraises the events within a hostile environment with high control potential then this shows hope (optimism); if the entrepreneur appraises the events within a hostile environment with low control potential then this shows fear (pessimism) related to the business. Appraising a situation with high or low control potential depends on the self-efficacy and focus of the entrepreneur. All the entrepreneurs of high performing companies appraised the environment 
that their businesses operate in as hostile and negative. However, most of them put a positive spin on this negativity and tried to find a silver lining.

Entrepreneur A of Company A is a firm believer that the higher the hos-

Table 5: Entrepreneurial appraisal cognition

\begin{tabular}{cccc}
\hline$\#$ & Company & Proposition variable & Presence \\
\hline 1 & Company A & Appraise high control potential & $\mathrm{Y}$ \\
2 & Company B & Appraise high control potential & $\mathrm{Y}$ \\
3 & Company C & Appraise high control potential & $\mathrm{Y}$ \\
4 & Company D & Appraise high control potential & $\mathrm{Y}$ \\
5 & Company E & Appraise high control potential & $\mathrm{N}$ \\
\hline
\end{tabular}

tility, the better it is. Higher hostility strangles away the weaker players and lets the stronger players emerge. He hires people capable of operating in hostile environments. This by no means infers that Entrepreneur A is a proponent of hostility. He is involved in committees related to security for the reduction of the hostility while simultaneously preaching that business heads learn to survive and thrive within this environment.

Entrepreneur B2 of Company B does not feel threatened by the regulatory fallout of the government, which is flooding the market with Chinese imports. He believes that the influx of Chinese businesses and products are not much of a threat to his business model as to him his company's and industry's products are far superior. Moreover, they have knowledge of the local economy, regulatory threats, and local demographics that the Chinese do not have. Even after a very stressful period when the regulators partially took over the company, he is confident that his company will come out at the top.

Entrepreneur C of Company $\mathrm{C}$ feels strongly pessimistic about the performance of the government and the hostile environment that it has created for businesses. He however, still points out the size of the market that Pakistan represents, the $\mathrm{R} \& \mathrm{D}$ of Company $\mathrm{C}$ that keeps them ahead of the competition, the company's value chain that keeps costs low, and the CSR initiatives that help local hospitals and non-profit organizations. Entrepreneur D of Company $\mathrm{D}$ talked about a recent meeting of the business heads with the Prime Minister. The entire agenda of the meeting addressed the regulatory problems of businesses. He believes that doing business locally will always have better odds of success. Entrepreneur E of Company E appraised the situation differently. He expressed dissatisfaction over the declining work ethics among the workforce. He mentioned that he had to show up at work every day because only then will his workers deliver the daily production.

\subsubsection{Fear}

Four of the entrepreneurs did not exhibit any fear related to their business. Entrepreneur A of Company A said that he and his team are a bunch of maniacs who thrive on the fact that they operate deep in the interior and away from the city where the support of his network, police, or even the army is non-existent. 
Entrepreneur B2 of Company B said that he felt annoyed rather than scared when someone attacked their company to divert their attention. Entrepreneur $\mathrm{C}$ of Company $\mathrm{C}$ believes that they can eliminate most threats (e.g., smuggling and companies operating unofficially) through strong R\&D. Entrepreneur D suggested that every problem is solvable.

Only Entrepreneur E expressed fear related to the continuation of his op-

Table 6: Entrepreneurial appraisal cognition negatively / fear

\begin{tabular}{cccc}
\hline$\#$ & Company & Proposition variable & Presence \\
\hline 1 & Company A & Fear & N \\
2 & Company B & Fear & N \\
3 & Company C & Fear & N \\
4 & Company D & Fear & N \\
5 & Company E & Fear & Y \\
\hline
\end{tabular}

erations. He fears that even the daily operations will not continue if he does not show up. He does not take any days off and works late into the night. He is unable to spend time with his family (wife, children, and grandchildren). He fears that his successors are incapable of continuing his business after his death. He worries about the rolling and eventual recovery of working capital stuck in the market as receivables, which represents almost $75 \%$ of his company's equity.

\subsubsection{Hope}

Four of the five entrepreneurs expressed hope for the future of their businesses operating within the hostile environment. Entrepreneur A had goals for the next

Table 7: Entrepreneurial appraisal cognition positively / hope

\begin{tabular}{cccc}
\hline \# & Company & Proposition variable & Presence \\
\hline 1 & Company A & Hope & Y \\
2 & Company B & Hope & Y \\
3 & Company C & Hope & Y \\
4 & Company D & Hope & Y \\
5 & Company E & Hope & N \\
\hline
\end{tabular}

five to ten years for his company. Entrepreneur B2 of Company B plans to make the brand of his company a household name throughout Pakistan. Despite economic and regulatory hostility, he is hopeful that the hostile environment will not get worse. Even if it does, his company is already working on international collaborations to mitigate the problem.

Entrepreneur C discussed major economic indicators, and implied that Pakistan is on the verge of bankruptcy (at worst) or tough regulatory measures related to austerity (at best). Despite this, he and his team were planning major expansion of their manufacturing operations. He believes that that no matter what happens to the country, the number one resource of the country is still 
in Pakistan (i.e., the 200 million people who are his company's customers). Entrepreneur D emphasized that everything is manageable. For him, hope can solve any problem and he hopes for opportunities in Pakistan. The only entrepreneur who is not hopeful is Entrepreneur E of Company E. To him, there is no need to depend on hope to manage a problem. He uses religion to forget the negativity around him; he explained that religion makes him forget everything.

\subsection{Other cognition process variables}

\subsubsection{Vision}

Most of the entrepreneurs had a clear vision that goes beyond personal interests. Their companies have been successful over a period of time, and were now looking for higher goals. Company A, for example, set a clear vision to improve the image of Pakistan internationally through its products. The CFO of Company B explained that the company is led by a visionary leader who wants to make his company a household recognized brand and wants to become a publicly listed firm. Company C hopes to be listed on the London stock exchange. Company D wants to improve every passing day and makes its own performance a standard for excellence rather than any external standard.

Entrepreneur E of Company E had the lowest level of motivation. He was

\begin{tabular}{clcc} 
Table 8: & Entrepreneurial cognition process-Visio \\
\hline \# & Company & Variable & Presence \\
\hline 1 & Company A & Vision & $\mathrm{Y}$ \\
2 & Company B & Vision & $\mathrm{Y}$ \\
3 & Company C & Vision & $\mathrm{Y}$ \\
4 & Company D & Vision & $\mathrm{Y}$ \\
5 & Company E & Vision & $\mathrm{N}$ \\
\hline
\end{tabular}

the only exception in this category, and just wants to take care of the company for the sake of his children. To him, it is not his responsibility to think about the current position of the country but rather take care of himself and his family.

\subsubsection{Being ethical}

Most of the entrepreneurs in this category of high performers pride themselves on being a part of the top tax payers of Pakistan. They complain that the overall taxes increase their unit price, which puts them at a disadvantage compared to companies in the same industry that do not pay taxes. They also point out that paying high taxes gives them leverage over the tax authorities and other regulators; these agencies and regulators are dependent on their companies to meet their own budgetary targets. The only exception is Company E. The majority of its sales stay outside the tax net; therefore, most of its capital is stuck in the market as receivable. 
M. Ilyas et al

Table 9: Entrepreneurial cognition process-Being ethical

\begin{tabular}{cccc}
\hline$\#$ & Company & Variable & Presence \\
\hline 1 & Company A & Paying taxes & Y \\
2 & Company B & Paying taxes & Y \\
3 & Company C & Paying taxes & Y \\
4 & Company D & Paying taxes & Y \\
5 & Company E & Paying taxes & N \\
\hline
\end{tabular}

\subsubsection{Knowledge and education}

"Entrepreneurial cognitions are the knowledge structures that people use to make assessments, judgments or decisions involving opportunity evaluation, venture creation and growth"(Mitchell et al 2002).

Knowledge and personality traits of entrepreneurs help in the formulation of

Table 10: Entrepreneurial cognition process-Education

\begin{tabular}{cccll}
\hline$\#$ & Company & Entrepreneur & Education & \multicolumn{1}{c}{ Source of Degree } \\
\hline 1 & Company A & Entrepreneur A & MBA & USA \\
2 & Company B & Entrepreneur B1 & Masters & Pakistan \\
3 & Company C & Entrepreneur C & FCMA & Pakistan Professional Body \\
4 & Company D & Entrepreneur D & BBA & Switzerland \\
5 & Company E & Entrepreneur E & Inter & Pakistan \\
\hline
\end{tabular}

business strategies. For knowledge, the researchers recorded the education levels of individuals (see table 10).

\section{Business strategies}

Entrepreneurial ventures and businesses within the country develop response strategies to counter the hostility that they experience in the business environment. These strategies take different forms for different businesses and depend on the intensity and the nature of business hostility. Response strategies include the following actions.

\subsection{Work force development}

One of the ways companies' counter business hostility is through workforce development/ employee training. Companies focus on grooming and preparing their employees so they are better able to operate in hostile environments without compromising business goals, growth, and values. They do this in a twofold manner. First, the companies try to recruit and hire people who meet the vigorous job description, and then they train and develop them according to the job.

Company A, B, C \& D believe in developing future executives by investing 
in them, treating them as members of the company rather than employees, soliciting input from them and giving weight to their points of view. Additionally, they have hired qualified executives for the formalization of the structure of the companies. Also, hiring specialized personnel like $\mathrm{PhDs}$, doctors and lawyers is being focused on.

Entrepreneur E has not hired anyone to run his company or eventually take it forward. He is the sole person running his company and looking after all operations.

This discussion highlights the attention paid to talent development by entrepreneurial leaders. Business leaders of entrepreneurial ventures are educated and/or experienced enough to realize the importance of $\mathrm{HR}$ as a viable source for battling and defeating business hostility by focusing on recruiting and developing the right people after assessing the business environment.

\subsection{Innovation and new product development}

$R \& D$ is the backbone of entrepreneurial success, and an important factor in mitigating business hostility. R\&D helps a business counter environmental threats, predict them, and develop strategies proactively rather than reactively. Entrepreneurial successes, such as Company A, Company B, and Company C, focus on strengthening their $R \& D$ teams. They have strong $R \& D$ and quality control (QC) teams. Entrepreneur A had deployed technology ten years ago that gave them a competitive advantage in the industry.

Company $\mathrm{E}$ however does not have any $\mathrm{R} \& \mathrm{D}$, and functions on traditional knowledge and the experience of the entrepreneur. It is succeeding due to lack of competition and is at the mercy of market dynamics.

\subsection{Insulate the leader from direct threats}

The leader of the entrepreneurial ventures is the soul and vision behind the company. It is important to protect the entrepreneur from physical and psychological threats in the business environment. The primary way companies accomplish this is by focusing on the brand and the company's product/service rather than on the entrepreneur. This protects the business leaders from over exposure.

For example, the ownership of Company $\mathrm{C}$ is not known to many people. Leadership of the company also avoids award ceremonies even if these ceremonies include the President of Pakistan or Prime Minister of Pakistan. Leaders of Company B and Company D do not meet people, give interviews to media, or attract social attention. Even when Company B was under scrutiny by the tax departments, Entrepreneur B2 said that Entrepreneur B1 (Owner) had no direct interaction with them. In contrast, Entrepreneur A embedded himself within different committees in the business community through which he developed a strong network to influence the security and regulatory agencies to mitigate threats to his company.

Entrepreneur E does not hide himself and is also readily available. This is

Business Review: (2018) 13(2):94-116 
not by design, but rather a consequence of not developing a good network of leaders around him. Entrepreneur E is not active anymore and does not have social networks. He is exposed to threats and directly faced kidnapping attempts, which the other entrepreneurs have not.

\subsection{Paying taxes}

Companies also counter business hostility by focusing on ethics in business processes, operations, and products. For example, Company B works on strong moral principles and never complies with unethical practices. Entrepreneur B2 explained that when faced with investigation from the tax departments, the company had taken a stand to not offer bribe. Entrepreneur C stated that ethics are the priority in Company $\mathrm{C}$, and are more important than revenue considerations.

Companies that comply with regulations and laws and pay their due taxation are leveraged against the regulator, providing them with a platform to repeatedly raise their concerns. Entrepreneur D is a diligent tax payer, proud of being among the top 100 tax payers in Pakistan. Despite this, he received multiple notices and they replied to each one of them. The biggest motivation to pay taxes is to obtain bargaining power with the regulators.

\subsection{Export/international partnerships}

Targeting international clients further hedges against drops in sales due to local instability. Company A exports $60 \%$ of its total production. Company B has opened retail outlets in the Middle East and Malaysia. Company $\mathrm{C}$ is the largest exporter of pharmaceutical drugs in Pakistan. Company D has agreements with international pharmaceutical companies, which allow Company D to manufacture pharmaceutical drugs for local sales through licenses. Company $\mathrm{E}$ is the only exception. It does not have international linkages nor does it export its products.

Table 11: Entrepreneurial actions-Summary

\begin{tabular}{lllllll}
\hline$\#$ & A & B & C & D & E & Strategy \\
\hline 1 & W.F.D & W.F.D & W.F.D & W.F.D & No & W.F.D \\
2 & R\&D & No & R\&D & No & No & R\&D \\
3 & Engaging & Insulated & Insulated & Insulated & Exposed & Leadership \\
4 & Tax payer & Tax payer & Tax payer & Tax payer & No & Paying taxes \\
5 & Product & Brand & Unique & Sole prop & Cap Int & Value of the \\
& knowledge & & molecules & & & company \\
6 & National & National & National & National & National & National \\
7 & Export & Export & Export & Export & None & \\
8 & Quality \& & Quality & Quality \& & Excellence & Quality & Customer \\
& excellence & & excellence & & & oriented \\
\hline
\end{tabular}


5.6 Quality and excellence

One way to achieve sustainability despite increasing environmental hostility is to focus on quality. All entrepreneurial successes maintain an undivided focus on product and service quality to appeal to customers and maintain their leading market positions. Entrepreneur A explained that one can make unlimited products but market needs quality, and that the people who are quality conscious are his customers. All firms focused on business strategies to ensure high and consistent quality to customers rather than battling environmental hostility or warding off competition.

For each of its departments, Company B has hired specialists who have vast industry knowledge and experience. Company $\mathrm{C}$ is the only company in Pakistan that has product liability insurance. It puts a unique bar code on every product, which the customer can verify through a mobile phone to check for counterfeit drugs. Entrepreneur D stated that he is in competition with himself all the time. It is important to improve every day. He talked about excellence and the efficiency of his company. At Company E, Entrepreneur E believes that the profit margin will increase automatically if the product is good.

A summary of the business strategies deployed by all the sample companies to deal with the hostile business environment is presented in table 11.

\section{Conclusion}

The purpose of the study was to propose sustainable strategies for entrepreneurs operating within hostile business environments. The researchers defined the hostile business environment with special emphasis on Pakistan, and justified the addition of terrorism/violent crimes in the definition of a hostile business environment. All the entrepreneurs in this study reported this variable as part of their cognitive process, cognitive appraisal, and subsequent actions (business strategies).

The results validate the researchers' assumption that terrorism/violent crime is an element of the hostile business environment and its presence can potentially exacerbate existing variables of hostile environments for businesses. Education has also been characterized as an important factor for firms' success. Education of the entrepreneur plays an important part in the cognition process. High performing entrepreneurs exhibit self-efficacy, focus, and a high level of education. One of the main factors influencing business growth is workforce development/retention, which allows them to avoid the direct hostility of the environment and let their executives or managers deal with it. This enables the entrepreneurs to maintain focus and avoid direct threats.

\section{References}

Abadie A, Gardeazabal J (2008) Terrorism and the world economy. European Economic Review 52(1):1-27

Ács ZJ, Audretsch DB (2006) Handbook of entrepreneurship research: An interdisciplinary survey and introduction, vol 1. Springer Science \& Business Media

Business Review: (2018) 13(2):94-116 
M. Ilyas et al

Adomako S, Opoku RA, Frimpong K (2018) Entrepreneurs' improvisational behavior and new venture performance: Firm-level and institutional contingencies. Journal of Business Research 83:10-18

Agyapong A, Amanor K, Poku K (2016) Antecedents to the implementation of hybrid strategy in a dynamic business environmentan econometric analysis of business decisions in ghana. Journal of Developmental Entrepreneurship 21(04):1650,025

Arieftiara D, Utama S, Wardhani R (2017) Environmental uncertainty as a contingent factor of business strategy decisions: Introducing an alternative measure of uncertainty. Australasian Accounting, Business and Finance Journal 11(4):116-130

Bandura A (1988) Organisational applications of social cognitive theory. Australian Journal of management 13(2):275-302

Bandura A (1999) Social cognitive theory: An agentic perspective. Asian journal of social psychology 2(1):21-41

Bandura A (2012) On the functional properties of perceived self-efficacy revisited

Bandura A, Cervone D (1983) Self-evaluative and self-efficacy mechanisms governing the motivational effects of goal systems. Journal of personality and social psychology 45(5):1017

Baum JR, Locke EA, Smith KG (2001) A multidimensional model of venture growth. Academy of management journal 44(2):292-303

Bentley-Goode KA, Newton NJ, Thompson AM (2017) Business strategy, internal control over financial reporting, and audit reporting quality. Auditing: A Journal of Practice \& Theory 36(4):49-69

Bonini S, Görner S (2011) The business of sustainability: Putting it into practice. McKinsey Global Survey Results

Brockhaus Sr RH (1980) Risk taking propensity of entrepreneurs. Academy of management Journal 23(3):509-520

Campos HM, Parellada FS, Valenzuela FAA, Rubio AM (2015) Strategic decision-making speed in new technology based firms. RAI Revista de Administração e Inovação 12(2):130152

Cooper AC, Gimeno-Gascon FJ, Woo CY (1991) A resource-based prediction of new venture survival and growth. In: Academy of Management Proceedings, Academy of Management Briarcliff Manor, NY 10510, vol 1991, pp 68-72

Covin JG, Slevin DP (1989) Strategic management of small firms in hostile and benign environments. Strategic management journal 10(1):75-87

Davis D, Morris M, Allen J (1991) Perceived environmental turbulence and its effect on selected entrepreneurship, marketing, and organizational characteristics in industrial firms. Journal of the Academy of Marketing Science 19(1):43-51

Eisenhardt KM (1989a) Building theories from case study research. Academy of management review 14(4):532-550

Eisenhardt KM (1989b) Making fast strategic decisions in high-velocity environments. Academy of Management journal 32(3):543-576

Eruemegbe GO (2015) Impact of business environment on organization performance in nigeriaa study of union bank of nigeria. European Scientific Journal, ESJ 11(10)

Forbes DP (1999) Cognitive approaches to new venture creation. International Journal of Management Reviews 1(4):415-439

Garbuio M, Dong A, Lin N, Tschang T, Lovallo D (2018) Demystifying the genius of entrepreneurship: How design cognition can help create the next generation of entrepreneurs. Academy of Management Learning \& Education 17(1):41-61

Gartner B (1989) Who is an entrepreneur is the wrong question? advances in entrepreneurship. Summer

Goulas E, Zervoyianni A (2013) Economic growth and crime: does uncertainty matter? Applied Economics Letters 20(5):420-427

Greenbaum RT, Dugan L, LaFree G (2007) The impact of terrorism on italian employment and business activity. Urban Studies 44(5-6):1093-1108

Hall WK (1980) Survival strategies in a hostile environment. Harvard Business Review $58(5): 75-85$

Hayton JC, George G, Zahra SA (2002) National culture and entrepreneurship: A review of behavioral research. Entrepreneurship theory and practice 26(4):33-52

Ivančić V, Mencer I, Jelenc L, Dulčić Ž (2017) Strategy implementation-external environment alignment. Management: journal of contemporary management issues 22(Special 
Issue):51-67

Jacobs B, Prentice-Dunn S, Rogers RW (1984) Understanding persistence: An interface of control theory and self-efficacy theory. Basic and Applied Social Psychology 5(4):333-347

Johnson BR (1990) Toward a multidimensional model of entrepreneurship: The case of achievement motivation and the entrepreneur. Entrepreneurship Theory and practice 14(3):39-54

Kaplan S (2008) Framing contests: Strategy making under uncertainty. Organization Science 19(5):729-752

Khandwalla P (1977) The structuring of organizations. Design of Organizations

Khandwalla PN (1976) Some top management styles, their context and performance. Organization and administrative sciences $7(4): 21-51$

Klepper S (2002) The capabilities of new firms and the evolution of the us automobile industry. Industrial and corporate change 11(4):645-666

Kotey B, et al (2014) Small business innovation in the hostile environment of australia's drought stricken rural communities. Australasian Journal of Regional Studies, The 20(2):325

Krueger Jr NF, Brazeal DV (1994) Entrepreneurial potential and potential entrepreneurs. Entrepreneurship theory and practice 18(3):91-104

Kyrgidou LP, Hughes M (2010) Strategic entrepreneurship: origins, core elements and research directions. European business review 22(1):43-63

Lindelöf P, Löfsten H (2006) Environmental hostility and firm behavioran empirical examination of new technology-based firms on science parks. Journal of Small Business Management 44(3):386-406

Lumpkin GT, Dess GG (1996) Clarifying the entrepreneurial orientation construct and linking it to performance. Academy of management Review 21(1):135-172

Miller D (2011) Miller (1983) revisited: A reflection on eo research and some suggestions for the future. Entrepreneurship Theory and Practice 35(5):873-894

Miller D, Friesen PH (1983) Strategy-making and environment: the third link. Strategic management journal 4(3):221-235

Mitchell RK, Smith B, Seawright KW, Morse EA (2000) Cross-cultural cognitions and the venture creation decision. Academy of management Journal 43(5):974-993

Mitchell RK, Busenitz L, Lant T, McDougall PP, Morse EA, Smith JB (2002) Toward a theory of entrepreneurial cognition: Rethinking the people side of entrepreneurship research. Entrepreneurship theory and practice 27(2):93-104

Mitchell RK, Busenitz LW, Bird B, Marie Gaglio C, McMullen JS, Morse EA, Smith JB (2007) The central question in entrepreneurial cognition research 2007. Entrepreneurship theory and practice $31(1): 1-27$

Nixdorff JL (2008) Unraveling the process: A qualitative study of entrepreneurial cognition in opportunity recognition. The George Washington University

Omar NA, Aris HM, Nazri MA (2016) The effect of entrepreneurial orientation, innovation capability and knowledge creation on firm performance: A perspective on small scale entrepreneurs. Jurnal Pengurusan (UKM Journal of Management) 48

Orbaneja JRV, Iyer SR, Simkins BJ (2018) Terrorism and oil markets: A cross-sectional evaluation. Finance Research Letters 24:42-48

Roseman IJ (1996) Appraisal determinants of emotions: Constructing a more accurate and comprehensive theory. Cognition \& Emotion 10(3):241-278

Rususup S, Isacsup F, Cureteanusup R, Csorbasup L, et al (2012) Entrepreneurship and entrepreneur: A review of literature concepts. African Journal of Business Management 6(10):3570-3575

Sexton DL, Bowman N (1985) The entrepreneur: A capable executive and more. Journal of business venturing 1(1):129-140

Torkkeli L, Puumalainen K, Saarenketo S, Kuivalainen O (2012) The effect of network competence and environmental hostility on the internationalization of smes. Journal of International Entrepreneurship 10(1):25-49

Vagnoni E, Khoddami S (2016) Designing competitivity activity model through the strategic agility approach in a turbulent environment. foresight 18(6):625-648

Wernerfelt B, Karnani A (1987) Competitive strategy under uncertainty. Strategic Management Journal 8(2):187-194

West III GP, Meyer GD (1998) Temporal dimensions of opportunistic change in technologybased ventures. Entrepreneurship Theory and Practice 22(2):31-52

Business Review: (2018) 13(2):94-116 
https://ir.iba.edu.pk/businessreview/vol13/iss2/6

DOI: https://doi.org/10.54784/1990-6587.1032

M. Ilyas et al

Wood R, Bandura A (1989) Social cognitive theory of organizational management. Academy of management Review 14(3):361-384

Zhu Z, Matsuno K (2016) Entrepreneurial proclivity: its environmental conditions and growth consequences. Journal of Strategic Marketing 24(1):20-33 